\title{
Pengembangan Instrument Tes Berpikir Kritis Gen-Z Dalam Materi Manusia dan Cinta
}

\author{
Subandri Simbolon', Hugo Theo Kurniason' ${ }^{2}$, Tetty Novitasari Simbolon ${ }^{3}$ \\ ${ }^{123}$ Sekolah Tinggi Agama Katolik Negeri Pontianak \\ ${ }^{1}$ subandri.simbolon@mail.ugm.ac.id, ${ }^{2 k u r n i a s o n h u g o t h e o @ g m a i l . c o m, ~}$ \\ ${ }^{3}$ simbolon.tettyn@gmail.com
}

\begin{tabular}{l}
\hline Keywords: \\
\hline Critical \\
Thinking; Gen-Z; \\
Test Instrument \\
Development
\end{tabular}

Kata Kunci:

Berpikir Kritis;

Gen-Z;

Pengembangan

Instrumen Tes

\begin{abstract}
A close correlation between gadgets and the internet makes it easier for Gen-Z to access information but tends to be low in critical thinking. Regrettably, the must-needed critical thinking process in absorbing information is usually missed as the process of copying or imitating all the information is way much easier to do. This research aims to develop a test instrument that can measure the critical thinking quality of Gen-Z (students at the Pontianak State Catholic High School). The test instrument developed focuses on the topic of humans and love, one of the materials contained in regional culture and multicultural subjects offered in the first semester. The test instrument developed using formative research can measure the quality of students' critical thinking. In addition, the test instrument has a value of validity, reliability, index of difficulty, and distinguishing power as determined.
\end{abstract}

\footnotetext{
Abstrak

Kedekatan yang sangat erat dengan gawai dan internet membuat gen-Z dimudahkan dalam akses informasi namun cenderung rendah dalam berpikir kritis. Proses berpikir kritis dalam menyerap informasi terlewatkan karena mencoba menyalin atau meniru semua informasi yang diterima. Riset ini bertunjuan untuk mengembangkan mengembangkan instrumen tes yang dapat mengukur kualitas berpikir kritis Gen-Z (mahasiswa di Sekolah Tinggi Agama Katolik Negeri Pontianak). Instrumen tes yang dikembangkan berfokus pada topik manusia dan cinta, salah satu materi yang terdapat pada mata pelajaran budaya daerah dan multikultural yang ditawarkan pada semester pertama. Instrumen tes dikembangkan dengan menggunakan penelitian formatif dapat mengukur kualitas berpikir kritis peserta didik. Selain itu, instrumen tes tersebut telah memiliki nilai validitas, reliabilitas, indeks kesukaran dan daya pembeda sesuai dengan yang ditentukan.
} 


\section{Pendahuluan}

Generasi merupakan suatu konstruksi sosial dimana di dalamnya terdapat sekelompok orang yang memiliki kesamaan umur dan pengalaman historis. Secara khusus Manheim (dalam Putra, 2016) menjelaskan bahwa elemen terkecil yaitu individu yang merupakan pecahan dari suatu kesatuan bernama generasi adalah individu yang memiliki kesamaan tahun lahir diukur dalam rentang 20 tahun dan berada dalam dimensi sosial serta sejarah yang sama. Karena dipengaruhi oleh peristiwa hidup yang sama, suatu kelompok generasi cenderung memiliki fase kehidupan yang sama yang akhirnya memengaruhi ingatan secara kolektif dan berpengaruh pada kehidupan mereka (Dencker, 2008).

Pembagian kelompok sebuah generasi berdasarkan kesamaan tahun kelahiran telah banyak di lakukan oleh banyak peneliti. Mukhlis (2015) membagi generasi kedalam empat generasi, yakni generasi baby boomer (lahir dari tahun 1946-1964), gen-X (lahir dari tahun 1965-1980), gen-Y (lahir dari tahun 1981-1994), dan gen-Z (lahir dari tahun 1995- 2010). Hal ini serupa dengan yang disampaikan oleh Grail Research mengenai pembagian terminologi generasi bahwa saat ini telah terdapat 4 generasi, yaitu generasi baby boomer, gen-X, Gen-Y, dan Gen-Z (Kusma, 2013). Menurut data BPS tahun 2017 mengenai jumlah penduduk, Gen-Z di Indonesia mencapai jumlah 68 juta jiwa.

Sejalan dengan berkembangnya pengetahuan, teknologi dan internet yang terjadi pada rentang waktu Gen-Z menimbulkan dampak yang signifikan pada kebutuhan hubungan sosial mereka melalui dunia maya. Gen-Z sudah diperkenalkan secara sengaja maupun tidak pada teknologi gawai dan mereka sangat akrab dengan smartphones. Tidak hanya akrab dengan teknologi dan gawai, generasi ini juga memiliki ciri-ciri umum, seperti menunjukkan reaksi cepat terhadap situasi di sekitarnya, pemrakarsa, multitasking, dan mudah menangkap informasi secara cepat (Putra, 2016). Menurut Husna (2018), Gen-Z memiliki nilai yang jauh berbeda dengan generasi sebelum mereka. Bagi Gen-Z, teknologi dan informasi telah menjadi bagian dari kehidupan mereka. Lahir pada zaman yang serba instan, menimbulkan perilaku enggan meluangkan waktu untuk berpikir kritits atas sebuah infomasi atau suatu masalah. Secara natural, generasi ini menyukai memecahkan masalah secara instan. Tidak hanya itu, generasi ini juga cenderung mencari solusi yang bersifat praktis atas sebuah masalah. Karakter seperti ini banyak ditemukan pada cara Gen-Z menjalankan harinya. Ketika mereka lapar namun 
sedang mengerjakan kegiatannya atau bahkan ketika rasa malas menyerang, generasi ini cenderung memesan makanan via online melalui berbagai jenis aplikasi.

Sebuah artikel yang ditulis oleh Bruce Tulgan (2013) berjudul "Meet Generation Z: The Second Generation within The Giant Millenial Cohort" yang didasarkan pada penelitian longitudinal sepanjang 2003 sampai dengan 2013, membagi lima karakteristik utama Gen Z.

1. Media sosial merupakan bagian kehidupan yang tidak bisa dipisahkan dari Gen-Z.

Gen-Z menggunakan media sosial sebagai jembatan atas keterasingan, karena semua orang dapat terhubung, berkomunikasi, dan berinteraksi.

2. Kebutuhan untuk terhubung dengan dunia luar secara maya adalah sebuah kebutuhan yang penting bagi Gen-Z.

3. Kesenjangan keterampilan pada generasi ini sangatlah besar karena adanya jarak nilai-nilai kehidupan yang sangat besar antara Gen-Z dan generasi sebelum mereka. Mengingat hal ini pula maka upaya menyalurkan keterampilan dari generasi sebelumnya seperti komunikasi interpersonal, budaya kerja, keterampilan teknis dan berpikir kritis menjadi sangat penting untuk dilakukan.

4. Meskipun pengalaman Gen-Z dalammenjelajah dunia secara geografis terbatas, kemampuan mereka dalam menggunakan teknologi dan internet memungkinkan mereka terhubung dengan banyak orang dari beragam belahan dunia yang kemudian berdampak pada karakter/pola pikir global (global mindset).

5. Karakter Gen-Z cenderung terbuka dalam menerima berbagai pandangan dan polapikir, namun efek negatif yang muncul jelas dalam karakter Gen-Z adalah mereka sulit mendefinisikan diri mereka sendiri. Identitas diri yang terbentuk seringkali berubah berdasarkan pada berbagai hal yang mempengaruhi mereka berpikir dan bersikap terhadap sesuatu.

Dalam mendukung proses pendidikan yang dapat menciptakan masyarakat yang cerdas baik dari sisi intelektual, emosional serta spiritualnya, pemerintah telah menyempurnakan kurikulum dalam rangka meningkatkan kualitas pendidikan nasional, dilakukan dengan menggantikan Kurikulum Tingkat Satuan Pendidikan (KTSP) menjadi Kurikulum 2013. Sesuai tuntutan kurikulum, pendidik wajib membuat dan memberikanpenilaian akhir terhadap peserta didik pada akhir pembelajaran. Asesmen/penilaian perlu dilakukan sebagai upaya untuk mengukur tingkat ketercapaian indikator pembelajaran dan mengumpulkan informasi perkembangan belajar peserta 
didik pada berbagai aspek (Astuti, 2012). Merujuk pada taksonomi Bloom, penilaian atau asesmen yang digunakan sebagai alat ukur tingkat keberhasilan pembelajaran, dan pencapaian tujuan-tujuan pembelajaran terdiri dari kemampuan berpikir tingkat rendah ke berpikir tingkat tinggi yang meliputi: 1) mengingat (remembering); 2) memahami (understanding); 3) menerapkan (applying); 4) menganalisis (analyzing); 5) mengevaluasi (evaluating); 6) menciptakan (creating). Taksonomi juga terdiri atas dimensi dari jenis pengetahuan yang saling berkaitan dengan taksonomi kemampuan berpikir.

Berpikir kritis bukan hanya sekedar dikembangkan pada proses pembelajaran belaka, namun juga wajib dibantu dengan instrumen penilaian berpikir kritis untuk memperoleh data atau informasi tentang kualitas pembelajaran yang layak dan untuk mengetahui apakah keterampilan berpikir kritis ini tercapai atau tidak (Baehaki, 2014). Ennis (1996) mengemukakan, “definisi berpikir kritis adalah berpikir secara beralasan dan reflektif dengan menekankan pembuatan keputusan tentang apayang harus dipercayai atau dilakukan".

Selanjutnya tentang pemahaman berpikir kritis, Fisher (2009:13) menjelaskan bahwah berpikir kritis adalah "aktivitas terampil, yang bisa dilakukan dengan lebih baik atau sebaliknya, dan pemikiran kritis yang baik akan memenui beragam standar intelektual, seperti kejelasan, relevansi, kecukupan, koherensi, dan lain-lain". Berdasarkan definisi tersebut, Fisher (2009:9) mengidentifikasi ada sembilan keterampilan berpikir kritis:

1. Mengidentifikasi elemen-elemen dalam kasus yang dipikirkan, khususnya alasanalasan dan kesimpulan-kesimpulan

2. Mengidentifikasi dan mengevaluasi asumsi-asumsi

3. Mengklarifikasi dan menginterpretasi pernyataan-pernyataan dan gagasan-gagasan

4. Menilai akseptabilitas, khususnya kredibilitas, klaim-klaim

5. Mengevaluasi argumen-argumen yang beragam jenisnya

6. Menganalisis, mengevaluasi, dan menghasilkan penjelasan-penjelasan

7. Menganalisis, mengevaluasi, dan membuat keputusan-keputusan

8. Menarik inferensi-inferensi

9. Menghasilkan argumen-argumen

Keterampilan berpikir kritis yang diajukan oleh Fisher menunjukkan bahwa berpikir kritis tidak hanya soal memami teks tetapi mengolah, menganalisis hingga mampu memhasilkan argumen. Lay dalam Zakiah, dkk. (2019:10) menegaskan poin-poin 
yang digagas oleh Fisher tersebut. Lay menyebutkan beberapa karakteristik yang harus dimiliki dalam kemampuan berpikir kritis:

1. Menganalisis argumen, klaim, atau bukti,

2. Membuat kesimpulan dengan menggunakan alasan induksi atau deduktif

3. Menilai atau mengevaluasi

4. Membuat keputusan atau memecahkan masalah

Berbeda dengan Fisher dan Lay, Bassham, dkk. menyebutkan poin-point penting dalam berpikir kritis dengan istilah intellectual standards. Menurut Bassham, dkk (2013:1) "critical thinking is dicipline thinking governed by clear intellectual standards. Artinya, berpikir kritis adalah disiplin berpikir yang diatur oleh standar intelektual yang jelas. Berdasarkan definisi ini, Bassham, dkk. (2013: 2-6) menjabarkan beberapa standar dalam berpikir kritis yakni: clarity, precision, accuracy, relevance, consistency, logical correctness, completeness, fairness.

Asesmen dan kemampuan berpikir kritis memiliki hubungan yang erat dimana di dalam asesmen terdapat upaya untuk mengumpulkan dan mengolah data atau informasi yang sahih (valid) dan reliabel dalam rangka melakukan pertimbangan untuk pengambilan kebijakan suatu program pendidikan. Soal yang baik juga memerlukan aspek lain yang mendukung kualitas soal. Menurut Arikunto (2006) sebuah soal yang terlalu mudah tidak merangsang siswa untuk meningkatkan usaha dalam memecahkannya. Instrumen asesmen yang terdiri dari soal pilihan jamak memiliki bagian opsi jawaban yang terbagi menjadi kunci jawaban dan jawaban pengecoh. Jawaban pengecoh berfungsi sebagai hal yang dapat mengukur apakah peserta tes memiliki kemampuan yang tinggi atau tidak (Mulyasa, 2009). Sensitivitas butir soal dinyatakan dengan indeks sensitivitas (S), yang dikenal sebagai suatu ukuran seberapa baik suatu butir soal dapat membedakan tingkat pemahaman antara siswa yang telah menerima pembelajaran dengan siswa yang belum menerima suatu pembelajaran (Sunyono, 2014). Suatu metode dan prosedur asesmen yang digunakan wajib disesuaikan dengan kondisi sebenarnya di sekolah. Namun faktanya belum banyak guru yang tahu bagaimana membuat serta menggunakan instrumen asesmen pengetahuan yang sesuai dengan dimensi pengetahuan dan kognitif yang akan diukur (Baehaki, 2014).

Peserta didik Sekolah Tinggi Agama Katolik Negeri Pontianak secara khusus pada semester 1 wajib mengambil mata kuliah Budaya Dasar dan Multikultur dimana di dalamnya mereka mendiskusikan dan belajar mengenai topik "Manusia dan Cinta". Topik 
ini menjadi menarik untuk dibahas karena pada dasarnya manusia dan cinta tidak dapat dipisahkan begitu saja. Pemahaman akan cinta merupakan suatu kebutuhan setiap manusia agar tidak terjerumus ke dalam upaya manipulasi cinta dan termanipulasi oleh karena alasan cinta. Menurut Caputo (2018), cinta selama ini dimaknai dengan tindakan memberikan kebaikan kepada orang yang baik, yang harus memiliki alasan untuk hadir. Adanya cinta itu merupakan suatu penipu, penyiasat, melayani-dirinya sendiri, penghianat. Cinta itu bisa menjadi suatu cara yang sangat cerdik untuk menguasai, menghianati, mengelabui dan melukai yang lain. Selain itu, cinta itu bisa menjadi suatu yang sangat eksklusif, dibatasi oleh kriteria-kriteria tertentu. Pemahaman seperti ini yang ditolak oleh Caputo. Caputo (2018: 4) menjelaskan "Love is not a bargain, but unconditional giving; it is not an investment, but a commitment come what may." Artinya, cinta bukanlah tawar menawar tetapi pemberian tanpa syarat, bukan investasi, tetapi sebuah komitment pada apapun yang terjadi. Dengan kata lain, cinta tidak punya alasan untuk hadir, cinta itu sendiri yang menjadi alasannya.

Materi cinta dan manusia menakar suatu cara berpikir kritis atas makna cinta yang diterima secara umum. Cinta, jika dipahami sebagai invenstasi, akan menjadi alat luar biasa untuk memanipulasi orang yang dicintai. Misalnya seorang peserta didik yang membantu temannya dengan harapan mendapatkan imbalan di masa depan, akan menjadikan temannya hidup dalam bayang-bayang "berhutang budi”. Pemikiran seperti ini lumrah bagi banyak orang. Peserta didik harus memiliki modal untuk berpikir kritis agar tidak menjadi pelaku dan korban manipulasi atas nama cinta.

Terutama di tengah kehidupan peserta didik yang umumnya berasal dari Gen-Z, dalam menkonsumsi berbagai informasi, mereka cenderung tidak menggunakan daya kritisnya. Dalam riset tentang skill abad 21, Trilling dan Fadel (2009) menemukan bahwa kompetensi lulusan sekolah menengah, diploma dan pendidikan tinggi masih kurang. Kompetensi yang dilihat adalah: komunikasi oral maupun tertulis, berpikir kritis dan mengatasi masalah, etika bekerja dan profesionalisme, bekerja secara tim dan berkolaborasi, bekerja dalam kelompok yang berbeda, penggunaan teknologi dan manajemen proyek dan kepemimpinan. Artinya, kemampuan berpikir kritis bagi gen-Z masih harus diperhatikan.

Alur pemikiran sebuah penelitian, apapun jenis penelitiannya dimulai dari adanya permasalahan atau ganjalan, yang merupakan suatu kesenjangan yang dirasakan oleh tim peneliti. Kesenjangan tersebut terjadi karena adanya perbedaan antara kondisi nyata 
dengan kondisi harapan. Dengan adanya kesenjangan ini tim peneliti mencari teori yang tepat untuk mengatasi permasalahan melalui penelitian, yaitu mencari tahu tentang kemungkinan penyebab kondisi yang menjadi masalah itu.

\section{Latihan}

Isilah soal-soal berikut ini!

h. Sebutkan beberapa bentuk cinta menurut Erich Fromm!

Gambar 1. Contoh Soal dalam Buku Teks

Pengembangan instrumen tes yang memfasilitasi kualitas berpikir kritis Gen-Z penting untuk dilakukan, satu diantaranya dalam materi Manusia dan Cinta. Berdasarkan pernyataan-pernyataan tersebut, peneliti tertarik untuk melakukan penelitian yang bertujuan mengembangkan instrumen tes yang dapat mengukur kualitas berpikir kritis Gen-Z dalam materi manusia dan cinta.

\section{Metode}

Penelitian ini menggunakan metode penelitian pengembangan, khususnya pengembangan instrumen tes berpikir kritis Gen-Z dalam materi manusia dan cinta. Pengembangan instrumen tes pada penelitian ini menggunakan pengembangan instrumen tes dengan formative research. Rincian tiap langkah dari formative research adalah self evaluation, one to one, expert review, small group, dan field test.

Pada langkah self evaluation, peneliti menentukan bentuk soal dan kisi-kisi soal yang akan dikembangkan. Adapun bentuk soal yang akan dikembangkan adalah uraian, sementara itu kisi-kisi soal menggunakan kisi-kisi dari kemampuan berpikir kritis. Setelah penentuan bentuk soal dan kisi-kisi, selanjutnya peneliti mengembangkan instrumen tes berdasarkan bentuk soal dan kisi-kisi yang telah ditentukan. Pada langkah self evaluation ini juga peneliti memeriksa kembali apakah soal tes tersebut sudah sesuai dengan tujuan pengukuran, yaitu mengukur kualitas berpikir kritis Gen-Z.

Langkah one to one ini menggunakan responden sebanyak enam orang peserta didik Sekolah Tinggi Agama Katolik Negeri Pontianak yang termasuk dalam Gen-Z serta telah mendapat materi manusia dan cinta dalam mata kuliah Ilmu Budaya Dasar dan Multikultur. Langkah one to one ini terbagi menjadi tiga sesi, yaitu sesi pertama peneliti menjelaskan petunjuk mengerjakan soal dan tujuan dilaksanakannya tes tersebut, sesi 
kedua meminta enam orang peserta didik tersebut mengerjakan soal yang telah dikembangkan peneliti, dan sesi ketiga peneliti mewawancarai keenam responden untuk mengetahui apakah redaksi pertanyaan pada soal sudah dapat dimengerti dengan baik dan durasi pengerjaannya kurang dari 120 menit. Selanjutnya pada langkah expert review, peneliti meminta dua orang yang dianggap ahli untuk melakukan validasi terhadap soal yang telah dikembangkan. Reviewer atau validator dalam penelitian ini adalah dosen dari Universitas Tanjungpura Pontianak dengan pendidikan terakhir doktor. Validasi mencakup isi materi, konstruksi pertanyaan, dan bahasa yang digunakan dalam soal.

Setelah melalui langkah one to one dan expert review, peneliti lenjut ke langkah small group. Pada langkah ini, peneliti mengujicobakan soal yang telah dikembangkan dalam skala kecil. Hasil dari small group ini akan dianalisis untuk memperoleh nilai validitas, reliabilitas, indeks kesukaran, dan daya pembeda dari setiap butir soal.

Langkah terakhir adalah field test. Pada langkah ini, peneliti mengujicobakan kembali soal yang telah dikembangkan, namun dengan skala yang lebih besar. Hasil dari field test ini juga akan dianalisis untuk memperoleh nilai validitas, reliabilitas, indeks kesukaran, dan daya pembeda dari setiap butir soal. Dalam penelitian ini, ketepatan instrumen tes yang dibuat didasarkan pada nilai validitas butir, reliabilitas, daya pembeda dan indeks kesukaran butir soal pada hasil uji coba soal. Kriteria yang ditetapkan adalah untuk validitas butir, minimal sedang; reliabilitas, minimal cukup; daya pembeda, minimal cukup; indeks kesukaran, harus sedang.

\section{Hasil dan Pembahasan}

\section{Produk Awal}

Instrumen tes yang akan dikembangkan dalam penelitian ini sebanyak 6 soal berbentuk uraian. Soal tes bertujuan untuk mengukur kualitas berpikir kritis gen-Z, serta diangkat dari materi ajar Manusia dan Cinta dalam mata kuliah Budaya Dasar dan Multikultur. Dalam pengembangan soal, peneliti menggunakan indikator-indikator yang diturunkan dari beberapa teori tentang berpikir kritis (Zakiah: 2019; Fisher: 2008; dan Bassham, dkk:2013). Sehingga indikator berpikir kritis yang digunakan adalah:

Tabel 1. Kisi-Kisi Soal Kualitas Berpikir Kritis gen-Z

\begin{tabular}{lc}
\hline \multicolumn{1}{c}{ Indikator Soal } & Nomor Soal \\
\hline Menganalisis argumen, klaim, bukti, atau penjelasan-penjelasan & 1,2 \\
\hline Mengevaluasi atau mengklarifikasi pernyataan atau gagasan & 3,4 \\
\hline Membuat keputusan atau kesimpulan & 5,6 \\
\hline
\end{tabular}


Setelah produk awal terbentuk, peneliti melakukan tahap pertama dari langkah pengembangan yaitu self evaluation. Pada langkah ini, peneliti memeriksa kembali apakah soal tersebut sudah sesuai dengan tujuan pengukuran, yaitu mengukur kualitas berpikir kritis gen-Z. Hasil dari langkah self evalution peneliti sebut dengan prototype I.

Prototype Soal I

1. Jelaskan teori Plato tentang cinta dan berikan tanggapan anda atas teori tersebut!

2. Apa yang anda pahami tentang teori Sigmund Freud tentang cinta sebagai dorongan sexual?

3. Sebagai martir pertama dalam Gereja Katolik, St. Stefanus diakui dalam hal keberaniannya sebagai saksi iman akan Kristus. Berikan evaluasi Anda terhadap tindakan St. Stefanus dalam perikop (Kis. 6:8-15; 7:54-60) dalam konteks makna cinta menurut Caputo!

4. Bacalah lirik lagu di Arti Cinta gubahan Ari Lasso. Lagu ini termasuk salah satu lagu yang hits di masanya. Dan banyak orang memahami makna cinta berdasarkan lirik lagu ini. Apakah anda setuju dengan makna cinta yang disampaikan oleh lagu ini? Kemukakan pula alasan anda!

5. Dalam Yesus disalibkan di bawah ini, kita percaya bahwa ini adalah peristiwa pengorbanan Yesus atas cinta-nya kepada manusia. Tunjukkan pemahaman anda atas Cinta tanpa tolok ukur Yesus berdasarkan gambar berikut ini!

6. Bagaimana seharusnya cinta seorang Ibu kepada anaknya menurut pemikiran Caputo? Jelaskan argumentasimu!

Gambar 2. Prototype Soal I Yang Digunakan Oleh Dosen Pengajar Untuk Mengevaluasi Pembelajaran Peserta Didik

Setelah langkah self evaluation, peneliti melanjutkan tahap pengembangannya ke langkah one to one dan expert review, dimana kedua langkah ini, peneliti lakukan secara paralel.

\section{Hasil Uji Coba}

Langkah one to one dilaksanakan pada Sabtu, 28 November 2020 secara online melalui Zoom Meetings. Langkah one to one ini diberikan kepada enam orang peserta didik angkatan 2018 semster 5 STAKat Negeri Pontianak yang telah mendapat materi Manusia dan Cinta dalam mata kuliah Budaya Dasar dan Multikultur. Pada langkah ini enam orang peserta didik tersebut diberikan soal dari prototype $I$.

Langkah one to one ini terbagi menjadi 3 sesi, yaitu sesi pertama pada pukul 15.30 - 16.00 WIB peneliti menjelaskan petunjuk mengerjakan soal dan tujuan diadakannya tes tersebut; sesi kedua pada pukul 16.00 - 18.00 WIB peneliti meminta peserta didik mengerjakan soal prototype I; dan sesi ketiga pada pukul 19.30 - 20.30 WIB peneliti meminta pendapat dan saran dari keenam peserta didik yang telah mengerjakan soal prototype $I$. 
Pada sesi ketiga, peneliti ingin mengkonfirmasi apakah redaksi pertanyaan pada soal sudah dapat dimengerti dengan baik dan durasi pengerjaan soal tersebut kurang dari 120 menit. Berdasarkan hasil one to one diperoleh durasi pengerjaan keenam peserta didik adalah sebagai berikut:

Tabel 2. Durasi Pengerjaan Soal Prototype I

\begin{tabular}{ccc}
\hline Kode Peserta didik & Waktu (WIB) & Durasi (menit) \\
\hline EM & $16.00-17.30$ & 90 \\
\hline HEV & $16.00-16.50$ & 50 \\
\hline IMN & $16.00-17.40$ & 100 \\
\hline KD & $16.00-16.55$ & 55 \\
\hline KS & $16.00-17.06$ & 66 \\
\hline MR & $16.00-17.40$ & 100 \\
\hline
\end{tabular}

Berdasarkan Tabel 2 diketahui bahwa durasi pengerjaan paling cepat adalah 50 menit, sedangkan pengerjaan paling lambat adalah 100 menit. Sehingga, dapat disimpulkan bahwa soal prototype I dapat diselesaikan dalam waktu 120 menit.

Berdasarkan pendapat keenam peserta didik yang mengerjakan soal prototype I, diperoleh pula saran bahwa soal nomor 4 yang mencantumkan lirik lagu Ari Lasso yang berjudul Arti Cinta diganti dengan lagu yang lebih terbaru. Apalagi mengingat sasaran dari soal tes ini adalah gen-Z yang kebanyakan tidak mengetahui lagu tersebut, karena rilis pada tahun 2004. Oleh karena itu, lirik lagu pada soal nomor 4 diganti dengan lirik lagu Judika yang berjudul Cinta Karena Cinta.

\section{Hasil Validasi Expert Review}

Langkah expert review dilaksanakan pada tanggal 20 - 30 November 2020. Reviewer atau validator dalam penelitian ini sebanyak dua orang dan merupakan dosen dari Universitas Tanjungpura Pontianak dengan pendidikan terakhir doktor. Soal yang divalidasi adalah soal dari prototypeI. Validasi prototypeI mencakup isi materi, konstruksi pertanyaan, dan bahasa yang digunakan dalam soal. Validasi ini sejalan dengan pendapat Gelerstein et al, (2016) yang menyatakan bahwa uji ahli dilakukan untuk memeriksa kesesuaian hubungan antara pertanyaan-pertanyaan dengan tujuan tes. Berikut ini adalah rangkuman dari hasil validasi kedua validator: 
Tabel 3. Ringkasan Hasil Validasi

\begin{tabular}{ccccccc}
\hline \multirow{2}{*}{ Nomor Soal } & \multicolumn{3}{c}{ Validator 1 } & \multicolumn{3}{c}{ Validator 2 } \\
\cline { 2 - 8 } & LD & LDP & TLD & LD & LDP & TLD \\
\hline 1 & - & $\sqrt{ }$ & - & $\sqrt{ }$ & - & - \\
\hline 2 & - & $\sqrt{ }$ & - & $\sqrt{ }$ & - & - \\
\hline 3 & $\sqrt{ }$ & - & - & $\sqrt{ }$ & - & - \\
\hline 4 & $\sqrt{ }$ & - & - & $\sqrt{ }$ & - & - \\
\hline 5 & - & $\sqrt{ }$ & - & $\sqrt{ }$ & - & - \\
\hline 6 & - & $\sqrt{ }$ & - & $\sqrt{ }$ & - & - \\
\hline
\end{tabular}

Keterangan:

LD: Layak digunakan

LDP: Layak digunakan dengan perbaikan

TLD: Tidak layak digunakan

Berdasarkan tabel 3 diketahui bahwa validator 1 menyarankan agar soal nomor 1, 2, 5, dan 6 untuk direvisi, sementara validator 2 walaupun dalam kesimpulannya menyebutkan soal nomor 1, 2, 3, 4, 5, dan 6 layak digunakan, namun tetap memberikan saran untuk perbaikan redaksi pertanyaan pada keenam soal. Oleh karena itu, peneliti merevisi redaksi pertanyaan untuk keenam soal prototype I. Revisi prototype I ini kemudian menjadi prototype II.

1. Jelaskan teori Plato tentang cinta dan berikan tanggapan Saudara atas teori tersebut!

2. Apa yang anda pahami tentang teori Sigmund Freud berkaitan dengan cinta sebagai dorongan seksual?

3. Sebagai martir pertama dalam Gereja Katolik, St. Stefanus diakui dalam hal keberaniannya sebagai saksi iman akan Kristus. Berikan evaluasi Saudara pada perikop (Kis. 6:8-15; 7:54-60) berkaitan dengan konteks makna cinta menurut Caputo!

4. Bacalah lirik lagu Cinta Karena Cinta (Judika). Lagu ini termasuk salah satu lagu yang hits di masa sekarang. Banyak orang memahami makna cinta berdasarkan lirik lagu ini. Apakah Saudara setuju dengan makna cinta yang disampaikan dalam lagu ini? Kemukakan alasan Saudara!

5. Dalam Yesus disalibkan di bawah ini, kita percaya bahwa ini adalah peristiwa pengorbanan Yesus atas cinta-nya kepada manusia. Tunjukkan pemahaman Saudara atas Cinta tanpa tolok ukur Yesus berdasarkan gambar berikut ini!

6. Bagaimana seharusnya cinta seorang Ibu kepada anaknya menurut pemikiran Caputo? Jelaskan argumentasi Saudara!

Gambar 3. Prototype Soal 2 Setelah Melewati Proses One To One Dan Expert Review

\section{Hasil Uji Coba Small Group (Uji Coba Terbatas)}

Langkah small group dilaksanakan pada Sabtu, 5 Desember 2020 secara online melalui Zoom Meetings. Langkah small group ini diberikan kepada enam belas orang peserta didik angkatan 2020 PKK 1 STAKat Negeri Pontianak yang telah mendapat materi Manusia dan Cinta dalam mata kuliah Ilmu Budaya Dasar dan Multikultur. Pada 
langkah ini enam belas orang peserta didik tersebut diberikan soal dari prototype II. Hasil uji coba pada small group ini akan dianalisis untuk mendapatkan nilai validitas butir, reliabilitas, daya pembeda, dan indeks kesukaran soal.

Validitas butir dalam penelitian ini menggunakan korelasi momen product. Hasil penghitungan validitas butir tiap soal prototype II adalah sebagai berikut:

Tabel 4. Validitas Butir Soal Prototype II pada Small Group

\begin{tabular}{ccc}
\hline \multirow{2}{*}{ Nomor Soal } & \multicolumn{2}{c}{ Validitas Butir } \\
\cline { 2 - 3 } & $\boldsymbol{r}$ & Kriteria \\
\hline 1 & 0,72 & Tinggi \\
\hline 2 & 0,59 & Sedang \\
\hline 3 & 0,81 & Sangat Tinggi \\
\hline 4 & 0,96 & Sangat Tinggi \\
\hline 5 & 0,89 & Sangat Tinggi \\
\hline 6 & 0,92 & Sangat Tinggi \\
\hline
\end{tabular}

Berdasarkan Tabel 4 diketahui bahwa ada 1 soal yang memiliki kriteria validitas butir sedang, 1 soal memiliki kriteria validitas butir tinggi, dan 4 soal memiliki kriteria validitas butir sangat tinggi. Sementara itu, untuk menghitung nilai reliabilitas soal prototype II digunakan rumus cronbach alpha. Hasil penghitungan reliabilitas untuk soal prototype II adalah 0,90 . Sehingga reliabilitas soal prototype II memiliki kriteria sangat tinggi. Selanjutnya, hasil penghitungan daya pembeda dan indeks kesukaran tiap soal prototype II adalah sebagai berikut:

Tabel 5. Daya Pembeda dan Indeks Kesukaran Soal Prototype II pada Small Group

\begin{tabular}{ccccc}
\hline \multirow{2}{*}{ Nomor Soal } & \multicolumn{2}{c}{ Daya Pembeda } & \multicolumn{2}{c}{ Indeks Kesukaran } \\
\cline { 2 - 5 } & DB & Kriteria & IK & Kriteria \\
\hline 1 & 0,28 & Cukup & 0,64 & Sedang \\
\hline 2 & 0,42 & Baik & 0,75 & Mudah \\
\hline 3 & 0,34 & Cukup & 0,70 & Sedang \\
\hline 4 & 0,50 & Baik & 0,66 & Sedang \\
\hline 5 & 0,38 & Cukup & 0,61 & Sedang \\
\hline 6 & 0,38 & Cukup & 0,64 & Sedang \\
\hline
\end{tabular}

Berdasarkan Tabel 5 diketahui bahwa ada 4 soal yang memiliki kriteria daya pembeda cukup dan 2 soal memiliki kriteria daya pembeda baik, serta ada 1 soal yang memiliki kriteria indeks kesukaran mudah dan 5 soal memiliki kriteria indeks kesukaran sedang. Berdasarkan analisis pada hasil small group diketahui bahwa keenam soal memenuhi indikator ketepatan. Sehingga, prototype II tidak direvisi. Selanjutnya, prototypeII akan diuji dalam field test. 


\section{Hasil Uji Coba Field Test}

Langkah field test dilaksanakan pada Sabtu, 12 Desember 2020 secara online melalui Zoom Meetings. Langkah field test ini diberikan kepada dua puluh tiga orang mahasiswa angkatan 2020 yang terdiri dari dua kelasSTAKat Negeri Pontianak yang telah mendapat materi Manusia dan Cinta dalam mata kuliah Budaya Dasar dan Multikultur. Di langkah ini dua puluh tiga orang mahasiswa tersebut diberikan soal dari prototype II.

Hasil uji coba pada field test ini juga akan dianalisis untuk mendapatkan nilai validitas butir, reliabilitas, daya pembeda, dan indeks kesukaran soal. Hasil penghitungan validitas butir tiap soal prototype II pada field test iniadalah sebagai berikut:

Tabel 6. Validitas Butir Soal Prototype II pada Field Test

\begin{tabular}{ccc}
\hline \multirow{2}{*}{ Nomor Soal } & \multicolumn{2}{c}{ Validitas Butir } \\
\cline { 2 - 3 } & $\boldsymbol{r}$ & Kriteria \\
\hline 1 & 0,77 & Tinggi \\
\hline 2 & 0,91 & Sangat Tinggi \\
\hline 3 & 0,91 & Sangat Tinggi \\
\hline 4 & 0,83 & Sangat Tinggi \\
\hline 5 & 0,81 & Sangat Tinggi \\
\hline 6 & 0,71 & Tinggi \\
\hline
\end{tabular}

Berdasarkan Tabel 6 diketahui bahwa ada 2 soal memiliki kriteria validitas butir tinggi dan 4 soal memiliki kriteria validitas butir sangat tinggi. Sementara itu, hasil penghitungan reliabilitas untuk soal prototype II pada field test adalah 0,90. Sehingga reliabilitas soal prototype II memiliki kriteria sangat tinggi. Menurut Istiyono, Mardapi, \& Suparno (2014) terdapat empat faktor yang menyebabkan validitas dan reliabilitas baik, yaitu (a) butir soal dikembangkan sesuai dengan prosedur pengembangan, (b) butir soal dikembangkan dari acuan yang tepat, (c) butir soal melalui tahap validasi isi, dan (d) butir soal diuji empiris dengan responden yang mengerjakan dengan sungguh-sungguh dan diawasi dengan ketat. Untuk point d, dalam penelitian ini, para responden tidak bisa diawasi dengan ketat karena faktor pandemik Covid-19. Namun, pengawasan tetap dilakukan mengadakan test via zoom seperti yang telah disampaikan sebelumnya. Hal ini senada dengan apa yang disampaikan oleh Hendriana dan Soemarno (2014:46) bahwa suatu alat ukur dikatakan valid apabila alat ukur tersebut benar-benar mengukur apa yang akan diukur. 
Selanjutnya, hasil penghitungan daya pembeda dan indeks kesukaran tiap soal prototype II pada field test ini adalah sebagai berikut:

Tabel 7. Daya Pembeda dan Indeks Kesukaran Soal Prototype II pada Field Test

\begin{tabular}{ccccc}
\hline \multirow{2}{*}{ Nomor Soal } & \multicolumn{2}{c}{ Daya Pembeda } & \multicolumn{2}{c}{ Indeks Kesukaran } \\
\cline { 2 - 5 } & DB & Kriteria & IK & Kriteria \\
\hline 1 & 0,44 & Baik & 0,68 & Sedang \\
\hline 2 & 0,53 & Baik & 0,68 & Sedang \\
\hline 3 & 0,54 & Baik & 0,65 & Sedang \\
\hline 4 & 0,52 & Baik & 0,66 & Sedang \\
\hline 5 & 0,45 & Baik & 0,67 & Sedang \\
\hline 6 & 0,37 & Cukup & 0,68 & Sedang \\
\hline
\end{tabular}

Berdasarkan Tabel 7 diketahui bahwa ada 1 soal yang memiliki kriteria daya pembeda cukup dan 5 soal memiliki kriteria daya pembeda baik, serta keenam soal tersebut memiliki kriteria indeks kesukaran sedang.

\section{Kesimpulan}

Kesimpulan penelitian ini adalah instrumen tes yang sudah dikembangkan dapat mengukur kualitas berpikir kritis peserta didik Gen-Z pada materi "Manusia dan Cinta". Selain itu, instrumen tes tersebut telah memiliki nilai validitas, reliabilitas, indeks kesukaran dan daya pembeda sesuai dengan yang ditentukan. Instrumen tes yang telah dikembangkan terdiri dari 6 soal berbentuk uraian. Beberapa saran yang dapat peneliti sampaikan berdasarkan kelemahan-kelemahan dalam penelitian ini adalah uji coba tidak dilakukan pada hari libur, dan soal untuk indikator mengevaluasi pernyataan dapat menggunakan berita atau info hoax terkini.

\section{Daftar Pustaka}

Abdullah Sani, R. (2014). Pembelajaran saintifik untuk implementasi kurikulum 2013. Jakarta: Bumi Aksara.

Andrisa, P. (2016). Pengaruh Kompetensi Dan Leader Member Exchange Terhadap Kinerja Karyawan PT Bukit Asam (Persero) Tbk Tarahan Port.Program Pascasarjana Magister Manajemen Fakultas Ekonomi dan Bisnis Universitas Lampung Bandar Lampung.

Arikunto. (2006). Prosedur Penelitian Suatu Pendekatan Praktek. Jakarta : PT. Rineka Cipta. 
Astuti, S. (2012). Upaya Peningkatan Motivasi Dan Hasil Belajar Matematika Siswa Melalui Metode Pembelajaran Edutainment (Education Entertainment) Siswa Kelas IV SD Negeri 2 Karangnongko Boyolali Tahun Ajaran 2011/2012. Skripsi. UMS. (tidak diterbitkan)

Bassham, G., Irwin, W., dkk. (2011). Critical Thinking. New York: McGraw Hill.

Baehaki. (2014). Pengaruh Media Pembelajaran Power Point Dan Gaya Belajar Siswa Terhadap Hasil Belajar. JTPPm (Jurnal Teknologi Pendidikan dan Pembelajaran) : Edutech and Intructional Research Journal), Vol 1, No 2.

BPS Indonesia dalam angka,2016 (https://www.bps.go.id/linkTabelStatis/view/id/1322 ) (diakses 23/11/2020)

Caputo, J. D. (2018). On religion. Routledge.

Dencker, J. C., Joshi, A., \& Martocchio, J. J. (2008). Towards a theoretical framework linking generational memories to workplace attitudes and behaviors. Human Resource Management $\quad$ Review, 18(3), 187. https://doi.org/10.1016/j.hrmr.2008.07.007

Ennis, R. H. (1996). Critical Thinking. New Jersey. Prentice-Hall Inc.

Fisher, Alec (2009). Critical Thinking, editor Gugi Sahara, Jakarta: Erlangga.

Gelerstein, D., Del Rio, R., Nussbaum, M., Chiuminatto, P., \& Lopez, X. (2016). Designing and implementing a test for measuring critical thinking in primary school. Thinking Skills and Creativity, 20, 40-49. https://doi.org/10.1016/j.tsc.2016.02.002

Hendriana, Heris dan Soemarmo, Utari. (2014). Penilaian Pembelajaran Matematika. Bandung: PT. Refika Aditama.

Husna, Asmaul. (2018). Diskursus "Aku Benci Narkoba" Dan Efek Kuasanya Terhadap Pelajar Makassar Yang Direhabilitasi Di Ykp2N Makassar. Jurnal Sosialisasi Pendidikan Sosiologis-FIS UNM.

Istiyono, E., Mardapi, D., \& Suparno. (2014). Pengembangan tes kemampuan berpikir tingkat tinggi Fisika (PysTHOTS) peserta didik SMA. Jurnal Penelitian dan Evaluasi Pendidikan, Vol. 18, No. 1, pp. 1-12.

Mukhlis. (2016). Pelatihan Kebersyukuran untuk Menurunkan Kecemasan Menghadapi Ujian Nasional pada Siswa SMA. Gadjah Mada Journal of Professional Psychology (GamaJPP), [S.1.], v. 1, n. 3, p. 203-215, feb. 2016. ISSN 2407-7801. Mulyasa, E. (2009). Menjadi Guru Profesional. Bandung: PT Remaja Rosdakarya. 
Putra, Y.S. 2016. Theoritical Review : Teori Perbedaan Generasi. Jurnal Ilmiah Among Makarti Vol.9 No.18.

Sunyono. (2014). Model Pembelajaran Berbasis Multipel Representasi dalam Membangun Model Mental dan Penguasaan Konsep Kimia Dasar Mahasiswa. Disertasi Doktor Program Pendidikan Sains. Pascasarjana Universitas Negeri Surabaya. Tidak Diterbitkan.

Trilling, B. and Fadel, C. (2009), 21st Century Skills: Learning for Life in Our Times. San Francisco, Calif., Jossey-Bass/John Wiley \& Sons, Inc

Tulgan, Bruce. 2013. Meet Generation Z: The second generation within the giant "Millennial" cohort. http:// rainmakerthinking.com/assets/uplo ads/2013/10/GenZ-Whitepaper.pdf diakses pada 10 Agustus 2020 Pk.09.48 WIB.

Zakiah, L. \& Lestari, I. (2019). Berpikir Kritis dalam Konteks Pembelajaran. Bogor: Erzatama Karya Abadi. 